\title{
Effect of Customers' Satisfaction on the Development of Hospitality and Tourism Industry in Bangladesh with Special Reference to Hotel City Inn Limited, Khulna
}

\author{
Afroza Parvin ${ }^{1}$, Rumana Perveen ${ }^{2}$, Jobayra Afsana ${ }^{3}$ \\ ${ }^{I}$ Assistant Professor of Finance, Department of Business Administration, Northern University Bangladesh, \\ Bangladesh) \\ ${ }^{2}$ (Senior Lecturer in Marketing, Department of Business Administration, Northern University Bangladesh, \\ Bangladesh) \\ ${ }^{3}$ (Lecturer in Management, Department of Business Administration, Northern University Bangladesh, \\ Bangladesh)
}

\begin{abstract}
This research paper has attempted to discover Effect of Customers' Satisfaction on the Development of Hospitality and Tourism Industry in Bangladesh with Special Reference to Hotel City Inn Limited, Khulna. This study has been conducted through sample survey of 150 customers (75 from room service and 75 from restaurant service) The study has used five broad satisfaction-specific factors named as reliability, responsiveness, assurance, empathy and tangible which have many sub factors. The most important satisfaction specific factor is tangible as it has got the highest mean value among five satisfaction specific factors. The regression model number one is showing that marital status, responsiveness, assurance and tangible have statistically significant effect on overall satisfaction level from restaurant services whereas for room service marital status, income, room booking system and responsiveness have statistically significant effect on the overall satisfaction. This research has also found that there is no statistically significant effect of overall customer' satisfaction from restaurant service on the development of hospitality and tourism industry in Bangladesh but there is statistically significant effect of overall customer' satisfaction from room service on the development of hospitality and tourism industry in Bangladesh.
\end{abstract}

Keywords: City Inn limited, Hospitality, Regression Analysis, Satisfaction, Tourism Industry.

\section{Introduction}

The charming beauty of Bangladesh mesmerized the tourists of the world. The Development of tourism industry plays a significant role in the economy of Bangladesh. Tourism in Bangladesh is a developing foreign currency earner. The country was listed by Lonely Planet in 2011 as the "best value destination" (www.wikipedia.com).

Kandampully (2000) defines tourism as a unique product as it is composite in nature, an amalgam of the tangible and intangible that includes everything that tourist's experience. Tourism has become an integral component of lifestyle and it has also become a major component of the economic prosperity of almost all countries. Nowadays one of the biggest challenges for managers in the hotel industry is to provide and sustain customers' satisfaction. Customer requirements for quality products and service in the tourism industry have become increasingly evident to professionals (Lam \& Zhang, 1999; Yen \& Su, 2004). Guest relationships are a strategic asset of the organization (Gruen et al., 2000) and customer satisfaction is the starting point to define business objectives. Every year tourists of different countries visit Bangladesh. For this reason satisfying tourists is essential. In the south-western part, mainly the Khulna Division, there is the Sundarban, the largest mangrove forest of the world with Royal Bengal Tiger and spotted deer (wikipedia.com). Hotel City Inn limited, Khulna is playing a contributory role to attract and satisfy the customers. This paper has measured the satisfaction level of customers of hotel City Inn Limited, Khulna as well as evaluated the role of the customers' satisfaction to the development of hospitality and tourism industry in Bangladesh.

\section{Objectives of the research}

This research paper has been conducted to achieve the followings objectives:

- To know the services offered by hotel City Inn Limited, Khulna.

- To evaluate the overall customers' satisfaction of hotel City Inn Limited, Khulna.

- To find out the factors those affect the customers' satisfaction from different services of Hotel City Inn, Limited, Khulna.

- To evaluate whether there is any effect of hotel customers' satisfaction on the development of hospitality and tourism industry in Bangladesh. 


\section{Research Methodology}

Methodology is the process or system through which a study is being carried out for the purpose of collecting of information that is required for reaching a conclusion on that study (Kothari, 2011). Customers' satisfaction level can be measured by different ways. This study has been conducted mainly based on primary data which has been collected from questionnaire survey among 150(75 from restaurant service and 75 from room service) individual tourists of hotel City Inn Limited, Khulna by using convenient sampling method. The questionnaire has been developed by taking help from a marketing textbook named as Services Marketing (Zeithmal et. al., 2011). This study considers the following five broad factors to measure the customers' satisfaction: Reliability, Responsiveness, Assurance, Empathy and Tangible. These factors have many sub factors to get a detail viewpoint about the tourist's satisfaction level. The questionnaire has been developed by using 5 point Likert-type scale consisting of assigned values between 1 to 5 where value $1=$ Strongly dissatisfied, 2= Dissatisfied, $3=$ Neutral, $4=$ Satisfied, $5=$ Strongly satisfied for the asked questions. Secondary data have been collected from articles of different journals, text books, websites etc. Collected data have been analyzed through descriptive statistics (frequency, percentage, mean, standard deviation) and multiple regressions by using SPSS version no.16. To achieve the objective no.2, 3 and 4 mentioned above the following hypotheses have been developed:

$\mathbf{H 1}_{\mathbf{0}}$ : There is no statistically significant effect of customer-specific factors (customer type, age, gender, marital status, income, profession, dining frequency) on individual customers' satisfaction level from restaurant service. $\mathbf{H} \mathbf{1}_{\mathrm{a}}$ : There is statistically significant effect of customer-specific factors (customer type, age, gender, marital status, income, profession, dining frequency) on individual customers' satisfaction level from restaurant service. $\mathbf{H 2}_{\mathbf{0}}$ : There is no statistically significant effect of satisfaction-specific factors (reliability, responsiveness, assurance, empathy and tangible) on individual customers' satisfaction level from restaurant service.

$\mathbf{H 2}_{\mathrm{a}}$ : There is statistically significant effect of satisfaction-specific factors (reliability, responsiveness, assurance, empathy and tangible) on individual customers' satisfaction level from restaurant service.

$\mathbf{H 3}_{\mathbf{0}}$ : There is no statistically significant effect of overall customer satisfaction level from restaurant service on the development of hospitality and tourism industry in Bangladesh.

$\mathbf{H 3}_{\mathbf{a}}$ : There is statistically significant effect of overall customer satisfaction level from restaurant service on the development of hospitality and tourism industry in Bangladesh.

$\mathbf{H 4}_{\mathbf{0}}$ : There is no statistically significant effect of customer-specific factors (customer type, room type, age, gender, marital status, income, profession, partner, purpose, booking system, hotel choosing reason) on individual customers' satisfaction level from room service.

$\mathbf{H 4}_{\text {a: }}$ : There is statistically significant effect of customer-specific factors (customer type, room type, age, gender, marital status, income, profession, partner, purpose, booking system, hotel choosing reason) on individual customers' satisfaction level from room service.

$\mathbf{H 5}_{\mathbf{0}}$ : There is no statistically significant effect of satisfaction-specific factors (reliability, responsiveness, assurance, empathy and tangible) on individual customers' satisfaction level from room service.

$\mathbf{H 5}_{\mathbf{a}}$ : There is statistically significant effect of satisfaction-specific factors (reliability, responsiveness, assurance, empathy and tangible) on individual customers' satisfaction level from room service.

H6: : There is no statistically significant effect of overall customers' satisfaction level from room service on the development of hospitality and tourism industry in Bangladesh.

H6 $_{\mathbf{a}}$ : There is statistically significant effect of overall customers' satisfaction level from room service on the development of hospitality and tourism industry in Bangladesh. For multiple regressions the following mode has been used: $Y=a_{0}+b_{1} x_{1}+b_{2} x_{2}+\ldots \ldots \ldots . .+b_{n} x_{n}$

Here, $\mathrm{Y}=$ dependent factor, $\mathrm{a}_{0}=$ constant $, \mathrm{x}_{1}, \mathrm{x}_{2}, \ldots \ldots \ldots \ldots \ldots \ldots \mathrm{x}_{\mathrm{n}}$ are the independent factors and $\mathrm{b}_{1}, \mathrm{~b}_{2}, \ldots \ldots \mathrm{b}_{\mathrm{n}}$ are the coefficients of the independent factors. Here for hypothesis no. 1-5 dependent factor is overall satisfaction level and for hypothesis no.6 dependent factor is development of hospitality and tourism industry in Bangladesh.

\section{Literature Review}

Akbaba and Atilla (2006) in the article "Measuring Service Quality in the Hotel Industry: A Study in a Business Hotel in Turkey" have found that five service quality dimensions named as "tangibles", "adequacy in service supply", "understanding and caring", "assurance", and "convenience". The findings showed that business travelers had the highest expectations for the dimension of "convenience" followed by "assurance", "tangibles", adequacy in service supply", and "understanding and caring". The research findings also confirmed that, although the SERVQUAL scale was a very useful tool as a concept, it needed to be adapted for the specific service segments and for the cultural context within which it was used.

Andaleeb and Conway (2006) in the paper on "Customer Satisfaction in the Restaurant Industry: an Examination of the Transaction-Specific Model" have used factor analysis and regressions model and 
suggested that customer satisfaction was influenced most by responsiveness of the frontline employees, followed by price and food quality (in that order). Physical design and appearance of the restaurant did not have a significant effect on customers' satisfaction.

Buhalis (2008) in the article "Twenty Years on and 10 years after the Internet: The state of eTourism Research" has revealed that innovative technologies will support interoperability, personalization and constant networking. Agile strategies are therefore required at both strategic and tactical management levels to ensure that the ICT driven opportunities and challenges are turned to the advantage of tourism organizations towards enhancing their innovation and competitiveness.

Camison (1996) in the article "Total Quality Management in Hospitality: An Application of the EFQM Model" has collected responses from 250 respondents to find out the gap between perception of the quality of their customers and self evaluation by their management on their companies' quality and performance with the help of European Quality Model.

Chi and Gurso (2009) in the article "Employee Satisfaction, Customer Satisfaction, and Financial Performance: An Empirical Examination" revealed that customer satisfaction has positive significant impact on financial performance, employee satisfaction has no direct significant impact on financial performance. Instead, there is an indirect relationship between employee satisfaction and financial performance, which is mediated by customer satisfaction.

Chu and Choi (2000) in the paper "An Importance-Performance Analysis of Hotel Selection Factors in the Hong Kong Hotel Industry: A Comparison of Business and Leisure Travelers" have identified six hotel selection factors such as Service, Quality, Business Facilities, Value, Room and Front Desk, Food and Recreation and Security. The study revealed that room and front desk and security were found to be the determining factors for business and leisure travelers, respectively, in their hotel choice selection.

Christina and Hailin (2008) in the article of "Examining the Structural Relationships of Destination Image, Tourist Satisfaction and Destination Loyalty: An Integrated Approach" have found that the theoretical and empirical evidence on the causal relationships among destination image, tourist attribute and overall satisfaction, and destination loyalty. A research model was proposed in which seven hypotheses were developed. The empirical data was collected in a major tourism destination in the state of Arkansas-Eureka Springs. The results supported the proposed destination loyalty model: (1) destination image directly influenced attribute satisfaction; (2) destination image and attribute satisfaction were both direct antecedents of overall satisfaction; and (3) overall satisfaction and attribute satisfaction in turn had direct and positive impact on destination loyalty.

Dominici and Guzzo (2010) in the paper on "Customer Satisfaction in the Hotel Industry: A Case Study from Sicily" have performed a qualitative analysis of a large hotel in Sicily (IT), the Sporting Club Hotel in the town Cefalu and used the Critical Incident Approach to measure customers' satisfaction. They found that the main factor which limits the Sporting Club Hotel's ability to achieve higher customer satisfaction levels is the standardization of services that reduces the possibility to customize the offer for specific guest needs. Indeed, from the unstructured interviews to the hotel's management it became apparent that the organizations adopt a "push" marketing approach.

Eraqi (2006) in the article "Tourism Services Quality (TourServQual) in Egypt The Viewpoints of External and Internal Customers" have revealed that for satisfying internal customers (employees) and external customers (tourists) it is necessary to ensure creative and innovative business environment, environmental conditions improvements, internal transport quality enhancement, increasing people awareness, and improving the level of safety and security conditions.

Heung (2000) in the article "Satisfaction Levels of Mainland Chinese Travelers with Hong Kong Hotel Services" has interviewed 203 mainland Chinese travelers and indicated that mainland Chinese travelers were satisfied with availability of personal care amenities, quietness of the room, availability of food and beverage variety and dissatisfied with recreation facilities, availability of frequent travelers' handling service. Eight dimensions of hotel services were identified. Service quality and value and augmented product quality dimensions were found to be more important than others in influencing their overall satisfaction levels and the likelihood of returning to the same hotels.

Kandampully and Suhartanto (2000) in the article on "Customer Loyalty in the Hotel Industry: the Role of Customer Satisfaction and Image" have identified the factors of image and customer satisfaction that are positively related to customer loyalty in the hotel industry. Using data collected from chain hotels in New Zealand, the findings indicate that hotel image and customer satisfaction with the performance of housekeeping, reception, food and beverage, and price are positively correlated to customer loyalty.

Blanc and Nguyen (1996), in the article of "An Examination of the Factors that Signal Hotel Image to Travelers" have found the five hotel factors that may signal a hotels image to travelers. These five factors were: physical environment, corporate identity, service personnel, quality of services and accessibility. They 
suggested that marketing effort should be directed to highlight the environmental cues in order to attract new customers.

Kozak and Rimmington (1998) in the article "Benchmarking: Destination Attractiveness and Small Hospitality Business Performance" have found that benchmarking offers advantages for small hospitality businesses and for the destinations where they are located.

Min et.al. (2002) “A Data Mining Approach to Developing the Profiles of Hotel Customers" have used 281 respondents of 11 different luxury hotels and suggested that in order to retain the customers' hotel management should consider different attributes such a customer's demographic profile, travel purpose, experience and availability of certain amenities.

Namkung and jang ( 2008) in the article "are Highly Satisfied Restaurant Customers Really Different?" a Quality Perception Perspective" have used logistic regression to determine which quality attributes are critical in distinguishing highly satisfied diners from other diners and found that appealing food presentation, tasty food, spatial seating arrangement, fascinating interior design, pleasing background music, reliable service, responsive service, and competent employees are important attributes in contributing to the high satisfaction of diners.

Nash et. al. (2006) in the article "An Investigation into Customer Satisfaction Levels in the Budget Accommodation Sector in Scotland: a Case Study of Backpacker Tourists and the Scottish Youth Hostels Association" have found that in terms of levels of importance and satisfaction (aspects of accommodationsignificance test) cleanliness of rooms, value for money and the presence of self-catering facilities were considered to be the most important factors.

Pizam and Ellis (1999) in the article "Customer Satisfaction and its Measurement in Hospitality Enterprises" have categorized different attributes as satisfiers, dissatisfies, critical and neutral .The results of the study have revealed that there is a difference between mediocre product and quality product and the process of monitoring customer satisfaction is beneficial to any hospitality enterprise.

Poon and Low (2005) in the article on "Are Travelers Satisfied with Malaysian Hotels?" have used factor analysis, multiple regression, and analysis of covariance (ANCOVA) and revealed that both Asian and Western travelers perceive hospitality as an influential factor in determining the overall satisfaction level and that satisfaction levels Malaysian hotels were higher among Western travelers than the Asian travelers. They used 200 respondents. It is noteworthy that Western travelers appear to be more concerned with the hotel appearance compared to Asians. Other hotel factors such as location, transportation, payment, and innovation and value-added services seem to be comparatively less influential in determining the overall satisfaction levels among both Asian and Western travelers. Nevertheless, hoteliers still need to ensure that the qualities of these hotel attributes are maintained at an acceptable level by constantly reviewing customers' feedback.

Sin et.al (2005) in the paper on "An Analysis of the Relationship between Market Orientation and Business Performance in the Hotel Industry" have collected data from 63 hotels in Hong Kong and revealed that market orientation is positively and significantly associated with the marketing performance and financial performance of a hotel.

Tsang and Qu (2000) in the paper on "Service Quality in China's Hotel Industry: A Perspective from Tourists and Hotel Managers" identified the perceptions of service quality in China's hotel industry from the perspective of both international tourists and hotel managers. They collected response from 90 hotel managers and 270 international tourists who visited China and stayed at hotels in Beijing, Shanghai, and Guangzhou. Descriptive statistics analysis was used (paired t-test and independent-test) to evaluate the service quality of China's hotel industry from both the tourists' and the managers' perspectives, and to investigate the four gaps: between tourists' expectations and their actual perceptions; between managers' perceptions of tourists' expectations and the actual expectations of tourists; between managers' perceptions of a hotel's service delivery and tourists' actual perceptions of the service; and between managers' perceptions of tourists' expectations and managers' perceptions of their hotel's service delivery. The results showed that tourists' perceptions of service quality provided in the hotel industry in China were consistently lower than their expectations and delivery, compared to tourists' perceptions of actual service quality.

Ryu et .al. (2007) in the paper on "The Relationships among Overall Quick-Casual Restaurant Image, Perceived Value, Customer Satisfaction, and Behavioral Intentions" have explored that customer satisfaction can act as a partial mediator in the relationship between overall quick-casual restaurant image/perceived value and behavioral intentions.

Yen and Su (2004) in the article "Customer Satisfaction Measurement Practice in Taiwan Hotels" have focused on hotel guest comment cards (GCCs) and customer satisfaction management schemes in Taiwan and indicated that the majority of hotel GCCs in Taiwan do not provide information for improving marketing information and these hotels do not allow for cross-referencing of findings to different market segments. 


\section{Profile Of Hotel City Inn Limited, Khulna}

Hotel City Inn Ltd superbly situated at the heart of Khulna; the industrial city of Bangladesh and very closer to the largest mangrove forest of the world "Sundarban", the heritage of globally renowned "Royal Bengal Tiger". Hotel City Inn Ltd. is palatial and designed with the most and modern Architecture. It is very excellently furnished and decorated, equipped with all modern facilities and filled with enjoyable atmospheres. At the hotel guests will receive the prompt and friendly services which they would expect from well trained, experienced staff blended with charming Bengali hospitality. Hotel City Inn Ltd. is one of the best wellestablished hotels in Khulna. The hotel City Inn Ltd. started their business with luxurious residential facilities high quality restaurant facilities with community center facility. It was opened in $16^{\text {th }}$ December, 2011.The community center facilities due to diversify their services in different types like conference facilities, recreational facilities, fitness center and health club, laundry and dry cleaning facilities etc. This hotel Offers different services for the guests such as Welcome Expression, Multi Cuisine Restaurant, Rooms are airconditioned and refrigerator,24-hour room service, Business Center with secretarial service, Printer, Scanner, Courier Service \& Photo Copier, Meeting Room, Conference Room \& Banquet Hall, Wi-Fi, Same day laundry service, Lift and Stand by Generator, Car parking and driver's accommodation, 24-hour security service \& CCTV, Doctor's on Call, Tour desk for sightseeing, Air-port transfer and Rent-a-Car, Major Credit Cards acceptable, Money Exchange facilities, Prayer Room, Gym, Swimming Pool, Digital Fire Management \& etc.

\subsection{Analysis of restaurant service}

\section{Analysis And Findings}

1.1.1. General analysis of customer-specific factors

Table No.1: Customer-Specific Factors (Restaurant Service)

\begin{tabular}{|c|c|c|c|}
\hline Factors & Category & Frequency & Percent \\
\hline \multirow{3}{*}{ Customer Type } & Local & 35 & 46.7 \\
\hline & Foreigner & 40 & 53.3 \\
\hline & Total & 75 & 100 \\
\hline \multirow{6}{*}{ Age } & Under 20 years & 8 & 10.7 \\
\hline & 20-30years & 6 & 8.0 \\
\hline & 30-40years & 5 & 6.7 \\
\hline & $40-50$ years & 16 & 21.3 \\
\hline & Above 50 years & 40 & 53.3 \\
\hline & Total & 75 & 100 \\
\hline \multirow{3}{*}{ Gender } & Male & 38 & 50.7 \\
\hline & Female & 37 & 49.3 \\
\hline & Total & 75 & 100.0 \\
\hline \multirow{3}{*}{ Marital Status } & Married & 38 & 50.7 \\
\hline & Unmarried & 37 & 49.3 \\
\hline & Total & 75 & 100.0 \\
\hline \multirow{6}{*}{ Profession } & Student & 20 & 26.7 \\
\hline & Businessman & 17 & 22.7 \\
\hline & Service holder & 5 & 6.7 \\
\hline & Housewife & 27 & 36.0 \\
\hline & Others & 6 & 8.0 \\
\hline & Total & 75 & 100.0 \\
\hline \multirow{6}{*}{ Income } & Below Taka 10,000 & 6 & 8.0 \\
\hline & Taka 10,000-Taka 20,000 & 13 & 17.3 \\
\hline & Taka 20,000-Taka 30,000 & 25 & 33.3 \\
\hline & Taka $30,000-$ Taka 40,000 & 22 & 29.3 \\
\hline & Above Taka 40,000 & 9 & 12.0 \\
\hline & Total & 75 & 100.0 \\
\hline \multirow{7}{*}{ Dining Frequency } & Daily & 15 & 20.0 \\
\hline & Weekly & 10 & 13.3 \\
\hline & Monthly & 12 & 16.0 \\
\hline & Once in three month & 13 & 17.3 \\
\hline & First time & 21 & 28.0 \\
\hline & Other & 4 & 5.3 \\
\hline & Total & 75 & 100.0 \\
\hline
\end{tabular}

Source: Field Survey, October-2014

Demographic characteristics of the respondents reveal that $46.7 \%$ local customers and $53.3 \%$ foreign customers stay in the hotel and the majority of the respondents $(53.3 \%)$ are above 50 years and $21.3 \%$ are between 40 and 50 years. Among them 50.7\% are male and $49.3 \%$ are female. 50.7\% of them are married and 49.3\% are unmarried. 36\% customers are housewives and $26.7 \%$ are students. Most of them (29.3\%) earn 
monthly Tk. 30,000- Tk 40000 and only few of them (12\%) earn above Tk 40000. Among them $28 \%$ has first time dining experience $20 \%, 13.3 \%$ and $16 \%$ have daily, weekly and monthly dining experience respectively.

1.1.2. General analysis of satisfaction-specific factors:

Table No. 2: Descriptive Statistics of Satisfaction-Specific Factors (Restaurant Service)

\begin{tabular}{|c|c|c|c|c|c|c|}
\hline Factors & $\mathbf{N}$ & Minimum & Maximum & Mean & Ranking & $\begin{array}{l}\text { Standard. } \\
\text { Deviation }\end{array}$ \\
\hline \multicolumn{7}{|l|}{ Reliability } \\
\hline I can depend on this hotel for further service & 75 & 2 & 5 & 3.98 & 1 & .871 \\
\hline The hotel performs service quickly & 75 & 2 & 5 & 3.95 & 2 & .868 \\
\hline My food order is correct and complete & 75 & 2 & 5 & 3.90 & 3 & .865 \\
\hline Quality of beverage is good & 75 & 2 & 5 & 3.71 & 4 & .851 \\
\hline The serve is excellent & 75 & 2 & 5 & 3.65 & 5 & .726 \\
\hline $\begin{array}{l}\text { The hotel performs the service according to } \\
\text { its promise }\end{array}$ & 75 & 2 & 5 & 3.32 & 6 & 1.10478 \\
\hline The food has a good value for taka & 75 & 2 & 5 & 3.31 & 7 & .900 \\
\hline The price is competitive & 75 & 1 & 5 & 3.29 & 8 & 1.088 \\
\hline Valid N (list wise) & 75 & & & & & \\
\hline \multicolumn{7}{|l|}{ Responsiveness } \\
\hline The hotel has online booking system & 75 & 2 & 5 & 3.9867 & 1 & 1.08420 \\
\hline $\begin{array}{l}\text { Employees respond to customer request } \\
\text { quickly }\end{array}$ & 75 & 1 & 5 & 3.2933 & 2 & 1.31286 \\
\hline Less time is taken for service delivery & 75 & 1 & 5 & 3.11 & 3 & 1.269 \\
\hline Valid N (list wise) & 75 & & & & & \\
\hline \multicolumn{7}{|l|}{ Assurance } \\
\hline Employees speak clearly & 75 & 3 & 5 & 4.19 & 1 & .630 \\
\hline Employees are well trained & 75 & 2 & 5 & 3.79 & 2 & .78 \\
\hline The hotel is a trusted one for getting service & 75 & 2 & 5 & 3.77 & 3 & .746 \\
\hline $\begin{array}{l}\text { Server was knowledgeable to answer my } \\
\text { question about the food and beverage }\end{array}$ & 75 & 2 & 5 & 3.77 & 4 & .746 \\
\hline Valid N (list wise) & 75 & & & & & \\
\hline \multicolumn{7}{|l|}{ Empathy } \\
\hline Employees are patient when taking my order & 75 & 2 & 5 & 4.20 & 1 & .717 \\
\hline Employees are friendly and courteous & 75 & 3 & 5 & 4.04 & 2 & .505 \\
\hline The serve is excellent & 75 & 2 & 5 & 3.65 & 3 & .726 \\
\hline Valid N (list wise) & 75 & & & & & \\
\hline \multicolumn{7}{|l|}{ Tangible } \\
\hline Sauces, utensils, napkins etc. are available & 75 & 3 & 5 & 4.64 & 1 & 607 \\
\hline The menu board is easy & 75 & 2 & 5 & 4.41 & 2 & .917 \\
\hline There is good food variety & 75 & 3 & 5 & 4.32 & 3 & 661 \\
\hline Food is hot and fresh & 75 & 2 & 5 & 4.09 & 4 & .791 \\
\hline Food temperature is accurate & 75 & 2 & 5 & 3.97 & 5 & .771 \\
\hline Food is tasty and flavorful & 75 & 2 & 5 & 3.75 & 6 & .680 \\
\hline Food quality is good & 75 & 2 & 5 & 3.56 & 7 & .683 \\
\hline Valid N (list wise) & 75 & & & & & \\
\hline
\end{tabular}

Source: Field Survey, October-2014

In reliability factor respondents want to depend on the hotel for further service as it has the highest mean value (3.98). But customers are not satisfied with the price of food as it has the lowest mean value (3.29).

Under responsiveness, the customers are satisfied with the hotel's online booking system as it got the highest mean value (3.98). But customers are not satisfied with the employees' service delivery time as it has the lowest mean value (3.11).

Under Assurance there are four variables. The customers are satisfied with the clearly speaking attitude of employees (4.19) but they are not satisfied with the server's knowledge to response their query about food and beverage as it has the lowest mean value (3.77).

Under Empathy customers give more emphasize on employees' patience while taking the order (4.20). On the other hand excellent service has the lowest mean value (3.65).

In tangible there are seven variables. Among them availability of sauces, utensils have got the highest mean value (4.64). On the other hand customers are not satisfied with the quality of food (3.56).

6.1.3. Regression between customer-specific factors and overall satisfaction from restaurant service

Model Summary

\begin{tabular}{|l|l|l|l|l|}
\hline Model & R & R Square & Adjusted R Square & Std. Error of the Estimate \\
\hline 1 & $.449^{\mathrm{a}}$ & .202 & .118 & 1.047 \\
\hline
\end{tabular}


ANOVA $^{\mathrm{b}}$

\begin{tabular}{|ll|l|l|l|l|l|}
\hline Model & & Sum of Squares & df & Mean Square & F & Sig. \\
\hline 1 & Regression & 18.571 & 7 & 2.653 & 2.421 & $.028^{\mathrm{a}}$ \\
& Residual & 73.429 & 67 & 1.096 & & \\
& Total & 92.000 & 74 & & & \\
\hline
\end{tabular}

a. Predictors: (Constant), customer type, age, gender, marital status, income, profession, dining frequency.

b. Dependent Variable: Overall satisfaction

Coefficients $^{\mathrm{a}}$

\begin{tabular}{|c|c|c|c|c|c|c|}
\hline \multirow{2}{*}{\multicolumn{2}{|c|}{ Model }} & \multicolumn{2}{|c|}{ Unstandardized Coefficients } & \multirow{2}{*}{\begin{tabular}{|l}
$\begin{array}{l}\text { Standardized } \\
\text { Coefficients }\end{array}$ \\
Beta
\end{tabular}} & \multirow[b]{2}{*}{$\mathrm{t}$} & \multirow[b]{2}{*}{ Sig. } \\
\hline & & B & Std. Error & & & \\
\hline \multirow[t]{8}{*}{1} & (Constant) & 2.096 & .871 & & 2.407 & .019 \\
\hline & Customer type & .583 & .389 & .263 & 1.499 & .139 \\
\hline & Age & -.066 & .182 & -.081 & -.361 & .719 \\
\hline & Gender & .412 & .326 & .186 & 1.261 & .212 \\
\hline & Marital Status & -.592 & .265 & -.267 & -2.234 & .029 \\
\hline & Profession & .123 & .121 & .154 & 1.013 & .315 \\
\hline & Income & .178 & .151 & .178 & 1.180 & .242 \\
\hline & Dining frequency & .069 & .080 & .100 & .860 & .393 \\
\hline
\end{tabular}

a. Dependent Variable: Overall satisfaction

Source: Field Survey, October-2014

The above model summary indicates that there remain a correlation between independent variables (customer type, age, gender, marital status, profession, income, dining frequency) and dependent variable (overall satisfaction from restaurant service). At 5\% significant level the correlation is $44.9 \%$. The value of adjusted R Square is .118. From ANOVA test it can be remarked that there is a statistically significant effect of marital status but there is no statistically significant effect of other variables (customer type, age, gender, profession, income, dining frequency).

So, Overall Satisfaction $=2.096+(.583)$ customer type $+(-.066)$ age $+(.412)$ gender $+(-.592)$ marital status + (.123) profession+ (.178) income+ (.069) dining frequency.

6.1.4. Regression between satisfaction-specific factors and overall satisfaction from restaurant service

Model Summary

\begin{tabular}{|l|l|l|l|l|}
\hline Model & R & R Square & Adjusted R Square & Std. Error of the Estimate \\
\hline 1 & $.620^{\mathrm{a}}$ & .385 & .340 & .906 \\
\hline
\end{tabular}

a. Predictors: (Constant) Reliability, Responsiveness, Assurance, Empathy, Tangible.

b. Dependent Variable: Overall satisfaction

ANOVA $^{b}$

\begin{tabular}{|ll|l|l|l|l|l|}
\hline Model & & Sum of Squares & df & Mean Square & F & Sig. \\
\hline 1 & Regression & 35.397 & 5 & 7.079 & 8.630 & $.000^{\mathrm{a}}$ \\
& Residual & 56.603 & 69 & .820 & & \\
& Total & 92.000 & 74 & & & \\
\hline
\end{tabular}

Predictors: (Constant), Reliability, Responsiveness, Assurance, Empathy, Tangible.

Source: Field Survey, October-2014

Coefficients $^{\mathrm{a}}$

\begin{tabular}{|c|c|c|c|c|c|c|}
\hline \multirow{2}{*}{\multicolumn{2}{|c|}{ Model }} & \multicolumn{2}{|c|}{ Unstandardized Coefficients } & \multirow{2}{*}{$\begin{array}{l}\text { Standardized Coefficients } \\
\text { Beta }\end{array}$} & \multirow[b]{2}{*}{$\mathrm{t}$} & \multirow[b]{2}{*}{ Sig. } \\
\hline & & B & Std. Error & & & \\
\hline \multirow[t]{3}{*}{1} & (Constant) & -4.676 & 1.405 & & -3.329 & .001 \\
\hline & Reliability & .116 & .345 & .056 & .337 & .737 \\
\hline & Responsiveness & .739 & .248 & .306 & 2.976 & .004 \\
\hline
\end{tabular}




\begin{tabular}{|c|c|c|c|c|c|}
\hline Assurance & .399 & .187 & .213 & 2.132 & .037 \\
\hline Empathy & -.085 & .323 & -.039 & -.264 & .793 \\
\hline Tangible & 1.028 & .355 & .346 & 2.899 & .005 \\
\hline
\end{tabular}

a. Dependent Variable: Overall satisfaction

Source: Field Survey October-2014

The above model summary indicates that there remains a correlation between independent variables (Reliability, Responsiveness, Assurance, Empathy and Tangible) and dependent variable (overall satisfaction from restaurant service). At 5\% significant level the correlation is $62 \%$. The value of adjusted R Square is .340 . From ANOVA test, it can be remarked that there is a statistically significant effect of Responsiveness, Assurance, and Tangible on overall satisfaction level from restaurant service but there is no statistically significant effect of other variables.

So, Overall Satisfaction $=-4.676+(.116)$ Reliability $+(.739)$ Responsiveness $+(.399)$ Assurance+ (-.085) Empathy + (1.028) Tangible.

6.1.5. Regression between overall satisfaction from restaurant service and development of hospitality and tourism industry in Bangladesh

Model Summary

\begin{tabular}{|l|l|l|l|l|}
\hline Model & $\mathrm{R}$ & R Square & Adjusted R Square & Std. Error of the Estimate \\
\hline 1 & $.132^{\mathrm{a}}$ & .018 & .004 & 1.07801 \\
\hline
\end{tabular}

a. Predictors: (Constant), overall satisfaction from restaurant service.

ANOVA
\begin{tabular}{|ll|l|l|l|l|l|}
\hline Model & & Sum of Squares & df & Mean Square & F & Sig. \\
\hline 1 & Regression & 1.513 & 1 & 1.513 & 1.302 & $.258^{\mathrm{a}}$ \\
& Residual & 84.833 & 73 & 1.162 & & \\
& Total & 86.347 & 74 & & & \\
\hline
\end{tabular}

a. Predictors: (Constant), overall satisfaction from restaurant service.

b. Dependent Variable: Development of hospitality and tourism industry in Bangladesh.

\section{Coefficients $^{\mathrm{a}}$}

\begin{tabular}{|c|c|c|c|c|c|c|}
\hline \multirow{2}{*}{\multicolumn{2}{|c|}{ Model }} & \multicolumn{2}{|c|}{ Unstandardized Coefficients } & \multirow{2}{*}{\begin{tabular}{|l} 
Standardized \\
Coefficients
\end{tabular}} & \multirow[b]{2}{*}{$\mathrm{t}$} & \multirow[b]{2}{*}{ Sig. } \\
\hline & & B & Std. Error & & & \\
\hline \multirow[t]{2}{*}{1} & (Constant) & 4.368 & .423 & & 10.319 & .000 \\
\hline & $\begin{array}{l}\text { Overall satisfaction from } \\
\text { restaurant service. }\end{array}$ & -.128 & .112 & -.132 & & .258 \\
\hline
\end{tabular}

a. Dependent Variable: Development of hospitality and tourism industry in Bangladesh.

The above model summary indicates that there remains a correlation between independent variable (Overall satisfaction from restaurant service) and dependent variable (Development of hospitality and tourism industry in Bangladesh). At 5\% significance level the correlation is $13.2 \%$. The value of adjusted R Square is 0.004 that means $0.4 \%$ of dependent variable can be explained by the independent variable. From ANOVA test, it can be remarked that there is no statistically significant effect of overall satisfaction from room service on development of hospitality and tourism industry in Bangladesh because significance level of the variable .258 which is greater than $5 \%$. Hence $\mathrm{H} 3_{0}$ is accepted and $\mathrm{H} 3_{\mathrm{a}}$ is rejected and the regression equation will be:

Development of hospitality and tourism industry in Bangladesh $=4.368+(-.128)$ overall satisfaction from restaurant service. 


\subsection{Analysis of room service}

6.2.1. General analysis of customer-specific factors

Table No. 3: Customer-Specific Factors (Room Service)

\begin{tabular}{|c|c|c|c|}
\hline Factors & Category & Frequency & Percent \\
\hline \multirow{3}{*}{ Customer Type } & Local & 41 & 54.7 \\
\hline & Foreigner & 34 & 45.3 \\
\hline & Total & 75 & 100 \\
\hline \multirow{4}{*}{ Room Type } & Low & 12 & 16 \\
\hline & Middle & 28 & 37.3 \\
\hline & High & 35 & 46.7 \\
\hline & Total & 75 & 100 \\
\hline \multirow{5}{*}{ Age } & $20-30$ years & 6 & 8.0 \\
\hline & 30-40years & 25 & 33.3 \\
\hline & 40-50years & 33 & 44.0 \\
\hline & Above 50 years & 11 & 14.7 \\
\hline & Total & 75 & 100 \\
\hline \multirow{3}{*}{ Gender } & Male & 49 & 65.3 \\
\hline & Female & 26 & 34.7 \\
\hline & Total & 75 & 100.0 \\
\hline \multirow{4}{*}{ Marital Status } & Married & 39 & 52.0 \\
\hline & Unmarried & 35 & 46.7 \\
\hline & Others & 1 & 1.3 \\
\hline & Total & 75 & 100.0 \\
\hline \multirow{6}{*}{ Profession } & Student & 11 & 14.7 \\
\hline & Businessman & 13 & 17.3 \\
\hline & Service holder & 13 & 17.3 \\
\hline & Housewife & 22 & 29.3 \\
\hline & Others & 16 & 21.3 \\
\hline & Total & 75 & 100.0 \\
\hline \multirow{6}{*}{ Income } & Below Taka 10,000 & 5 & 6.7 \\
\hline & Taka 10,000-Taka 20,000 & 6 & 8.0 \\
\hline & Taka 20,000-Taka 30,000 & 16 & 21.3 \\
\hline & Taka $30,000-$ Taka 40,000 & 44 & 58.7 \\
\hline & Above Taka 40,000 & 4 & 5.3 \\
\hline & Total & 75 & 100.0 \\
\hline \multirow{6}{*}{ Partner in travelling } & Wife and children & 7 & 9.3 \\
\hline & Parents & 1 & 1.3 \\
\hline & Collogues & 28 & 37.3 \\
\hline & Friends & 8 & 10.7 \\
\hline & None & 31 & 41.3 \\
\hline & Total & 75 & 100.0 \\
\hline \multirow[t]{5}{*}{ Purpose of the trip } & Holiday & 15 & 20.0 \\
\hline & Business & 12 & 16.0 \\
\hline & Hobby & 2 & 2.7 \\
\hline & Service & 46 & 61.3 \\
\hline & Total & 75 & 100.0 \\
\hline \multirow[t]{5}{*}{ I usually book the room } & By Phone & 32 & 42.7 \\
\hline & Directly from hotel & 14 & 18.7 \\
\hline & From travel agency & 11 & 14.7 \\
\hline & I do not book in advance & 18 & 24.0 \\
\hline & Total & 75 & 100.0 \\
\hline \multirow[t]{6}{*}{ Reason of hotel choosing } & Good Location \& Price & 29 & 38.7 \\
\hline & Additional service provided & 14 & 18.7 \\
\hline & Someone recommended hotel to me & 17 & 22.7 \\
\hline & $\begin{array}{l}\text { You had good experience from this } \\
\text { hotel }\end{array}$ & 11 & 14.7 \\
\hline & All of the above & 4 & 5.3 \\
\hline & Total & 75 & 100.0 \\
\hline
\end{tabular}

Source: Field Survey October 2014

Demographic characteristics of the respondents reveal that $54.7 \%$ local customers and $45.3 \%$ foreign customers stayed in the hotel during the survey period. And most of the respondents (46.7\%) have stayed in luxurious rooms and only $16 \%$ have stayed in low quality room. The majority of the respondents $(44 \%)$ are in between $40-50$ years and $8 \%$ is in between 20 and 30 years. This research has used $65.3 \%$ are male and $34.7 \%$ are female customers. $52 \%$ of them are married and $46.7 \%$ are unmarried, $29.3 \%$ customer is housewife and $14.7 \%$ is student. Most of them (58.7\%) earn monthly Tk. 30,000- Tk 40,000 and only few of them (5.3\%) earn 
above Tk. 40,000. Among them 37.3\% have traveled with collogues and 41.3\% have traveled alone. $61.3 \%$ have traveled for service purpose and only $2.7 \%$ have traveled for hobby. Maximum respondents (42.7\%) have followed phone booking system and only $14.7 \%$ have booked hotel from travel agency. Maximum respondents $(38.7 \%)$ have chosen the hotel for good location and price and few of them have chosen $(14.7 \%)$ hotel for good past experience.

\subsubsection{General analysis of satisfaction-specific factors}

Table No. 4: Satisfaction-Specific Factors (Room Service)

\begin{tabular}{|c|c|c|c|c|c|c|}
\hline Reliability & $\mathbf{N}$ & Minimum & Maximum & Mean & Ranking & $\begin{array}{l}\text { Std. } \\
\text { Deviation }\end{array}$ \\
\hline $\begin{array}{l}\text { The hotel performs the service according to its } \\
\text { promise }\end{array}$ & 75 & 2 & 5 & 3.98 & 1 & .870 \\
\hline I can depend on this hotel for further service & 75 & 2 & 5 & 3.95 & 2 & .868 \\
\hline Hotel performs service quickly & 75 & 1 & 5 & 3.29 & 3 & 1.088 \\
\hline Valid N (list wise) & 75 & & & & & \\
\hline \multicolumn{7}{|l|}{ Responsiveness } \\
\hline The hotel has online booking system & 75 & 1 & 5 & 3.3 & 1 & 1.33 \\
\hline $\begin{array}{l}\text { Employees respond to customer request } \\
\text { quickly }\end{array}$ & 75 & 1 & 5 & 3.2933 & 2 & 1.31286 \\
\hline The hotel has baggage counter & 75 & 1 & 5 & 2.7533 & 3 & 1.45635 \\
\hline $\begin{array}{l}\text { Employees are willing to hear customer } \\
\text { problem }\end{array}$ & 75 & 1 & 5 & 2.7333 & 4 & 1.43634 \\
\hline Valid N (list wise) & 75 & & & & & \\
\hline \multicolumn{7}{|l|}{ Assurance } \\
\hline The employees are trained & 75 & 2 & 5 & 3.78 & 1 & .766 \\
\hline The hotel is a trusted one for getting service & 75 & 2 & 5 & 3.77 & 2 & .746 \\
\hline $\begin{array}{l}\text { Server was knowledgeable to answer my } \\
\text { question about the food and beverage }\end{array}$ & 75 & 2 & 5 & 3.75 & 3 & .745 \\
\hline Valid N (list wise) & 75 & & & & & \\
\hline \multicolumn{7}{|l|}{ Empathy } \\
\hline Employees understand customers' needs. & 75 & 2 & 5 & 3.77 & 1 & .746 \\
\hline The hotel meets customers' expectation & 75 & 1 & 5 & 3.29 & 2 & 1.088 \\
\hline Employees are careful to the customer & 75 & 1 & 5 & 3.28 & 3 & 1.087 \\
\hline Valid N (list wise) & 75 & & & & & \\
\hline \multicolumn{7}{|l|}{ Tangibles } \\
\hline Speed of internet connection is good & 75 & 2 & 5 & 3.97 & 1 & .788 \\
\hline Quality of hotel's room is good & 75 & 2 & 5 & 3.79 & 2 & .664 \\
\hline Reception quality and condition is good & 75 & 2 & 5 & 3.77 & 3 & .669 \\
\hline Employees understand customer's needs. & 75 & 2 & 5 & 3.75 & 4 & .744 \\
\hline Quality of lobby is good & 75 & 2 & 5 & 3.53 & 5 & .644 \\
\hline Quality of breakfast is good & 75 & 3 & 5 & 3.51 & 6 & .601 \\
\hline $\begin{array}{l}\text { Hotel's price quality ratio satisfies } \\
\text { expectation }\end{array}$ & 75 & 2 & 5 & 3.47 & 7 & .890 \\
\hline Quality of restaurant is good & 75 & 2 & 6 & 3.43 & 8 & .640 \\
\hline Hotel meets my expectation & 75 & 1 & 5 & 3.29 & 9 & 1.088 \\
\hline Employees are careful to the customer's needs & 75 & 1 & 5 & 3.27 & 10 & 1.087 \\
\hline Functionality and tidiness of evaluator is good & 75 & 2 & 5 & 3.28 & 11 & .627 \\
\hline $\begin{array}{l}\text { Functionality of parking and number of } \\
\text { parking lots is satisfactory }\end{array}$ & 75 & 2 & 4 & 3.19 & 12 & .562 \\
\hline Valid N (list wise) & 75 & & & & & \\
\hline
\end{tabular}

Source: Field Survey October 2014

In reliability factor respondents want to depend on the hotel for 'performing the service according to its promise' as it has the highest mean value (3.98). But customers are not satisfied with the factor 'performing service quickly' as it has the lowest mean value (3.29).

Under responsiveness, the customers are satisfied with the hotels for 'online booking services' as it got the highest mean value (3.3). But customers are not satisfied with the 'employees' willingness to hear their problem' as it has the lowest mean value (2.7333).

Under Assurance there are three variables. The customers are satisfied with 'trained employees' (3.78). But they are not satisfied with the 'server's knowledge to response their query about food and beverage' as it has the lowest mean value (3.75).

Under Empathy customers give more emphasize on 'employees' better understanding capability' (3.77). On the other hand in tangible there are ten variables. Among them 'speed of internet connection' has got the highest mean value (3.97). On the other hand, customers are not satisfied with 'parking facility' (3.19). 
6.2.3. Regression between overall satisfaction from room service and customer-specific factors

Model Summary

\begin{tabular}{|l|l|l|l|l|}
\hline Model & R & R Square & Adjusted R Square & Std. Error of the Estimate \\
\hline 1 & $.513^{\mathrm{a}}$ & .264 & .135 & 1.142 \\
\hline
\end{tabular}

a. Predictors: (Constant), customer type, room type, age, marital status, profession, income, partner, purpose, booking system, hotel choosing reason.

ANOVA $^{\text {b }}$

\begin{tabular}{|ll|l|l|l|l|l|}
\hline Model & Sum of Squares & df & Mean Square & F & Sig. \\
\hline 1 & Regression & 29.404 & 11 & 2.673 & 2.050 & $.038^{\mathrm{a}}$ \\
& Residual & 82.142 & 63 & 1.304 & & \\
& Total & 111.547 & 74 & & & \\
& & & & & & \\
\end{tabular}

a. Predictors: (Constant), t type, room type, age, marital status, profession, income, partner, purpose, booking system, hotel choosing reason.

b.Dependent Variable: Overall satisfaction from room service

Coefficients $^{\mathrm{a}}$

\begin{tabular}{|c|c|c|c|c|c|c|}
\hline \multirow{2}{*}{\multicolumn{2}{|c|}{ Model }} & \multicolumn{2}{|c|}{ Unstandardized Coefficients } & \multirow{2}{*}{\begin{tabular}{|l} 
Standardized Coefficients \\
Beta
\end{tabular}} & \multirow[b]{2}{*}{$\mathrm{t}$} & \multirow[b]{2}{*}{ Sig. } \\
\hline & & B & Std. Error & & & \\
\hline \multirow[t]{12}{*}{1} & (Constant) & 1.099 & 1.168 & & .941 & .350 \\
\hline & Customer type & -.457 & .372 & -.186 & -1.229 & .224 \\
\hline & Room type & .359 & .234 & .215 & 1.537 & .129 \\
\hline & Age of the respondents & -.154 & .174 & -.114 & -.883 & .380 \\
\hline & Gender of the respondents & .168 & .381 & .065 & .441 & .661 \\
\hline & Marital status of the guest & .660 & .325 & .285 & 2.032 & .046 \\
\hline & Profession of the restaurant & -.094 & .124 & -.105 & -.761 & .449 \\
\hline & income level of the respondents & .429 & .206 & .337 & 2.082 & .041 \\
\hline & Partner in traveling & -.056 & .125 & -.058 & -.447 & .657 \\
\hline & Purpose of the trip & .077 & .117 & .079 & .657 & .514 \\
\hline & I usually book in room & .260 & .102 & .340 & 2.540 & .014 \\
\hline & I have chosen this hotel & -.053 & .122 & -.055 & -.437 & .664 \\
\hline
\end{tabular}

a. Dependent Variable: Overall you are satisfied from room service of the hotel

Source: Field Survey October-2014

The above model summary indicates that there remains a correlation between independent variable (customer type, room type, age, marital status, profession, income, partner, purpose, booking system, hotel choosing reason) and dependent variable (overall satisfaction from room service). At 5\% significant level the correlation is $51.3 \%$. The value of adjusted $\mathrm{R}$ Square is .135.

From ANOVA test it can be remarked that there is a statistically significant effect of marital status but there is no statistically significant effect of others variables (customer type, room type, age, gender, profession, income, partner, purpose, booking system, choosing reason).

So, Overall Satisfaction $=1.099+(-.457)$ customer type+ $(.359)$ room type+ $(-.154)$ age $+(.168)$ gender $+(.660)$ marital status $+(-.094)$ profession $+(.429)$ income $+(-056)$ partner $+(.077)$ purpose $+(.260)$ booking system $+(-.053)$ choosing reason.

6.2.4. Regression between overall satisfaction from room service and satisfaction-specific factors

Model Summary (Room)

\begin{tabular}{|l|l|l|l|l|}
\hline Model & R & R Square & Adjusted R Square & Std. Error of the Estimate \\
\hline 1 & $.541^{\mathrm{a}}$ & .293 & .242 & 1.069 \\
\hline
\end{tabular}

a. Predictors: (Constant), Reliability, Responsiveness, Assurance, Empathy, Tangible. 
ANOVA $^{\text {b }}$

\begin{tabular}{|ll|l|l|l|l|l|}
\hline Model & & Sum of Squares & df & Mean Square & F & Sig. \\
\hline 1 & Regression & 32.671 & 5 & 6.534 & 5.716 & $.000^{\mathrm{a}}$ \\
& Residual & 78.876 & 69 & 1.143 & & \\
& Total & 111.547 & 74 & & & \\
\hline
\end{tabular}

a. Predictors: (Constant), Reliability, Responsiveness, Assurance, Empathy, Tangible.

b. Dependent Variable: Overall satisfaction from room service.

Coefficients $^{\mathrm{a}}$

\begin{tabular}{|c|c|c|c|c|c|c|}
\hline \multirow{2}{*}{\multicolumn{2}{|c|}{ Model }} & \multicolumn{2}{|c|}{ Unstandardized Coefficients } & \multirow{2}{*}{\begin{tabular}{|l} 
Standardized \\
Coefficients
\end{tabular}} & \multirow[b]{2}{*}{$\mathrm{t}$} & \multirow[b]{2}{*}{ Sig. } \\
\hline & & B & Std. Error & & & \\
\hline \multirow[t]{6}{*}{1} & (Constant) & .208 & 1.486 & & .140 & .889 \\
\hline & Reliability & .035 & .237 & .021 & .147 & .884 \\
\hline & Responsiveness & 1.003 & .210 & .529 & 4.765 & .000 \\
\hline & Assurance & -.034 & .190 & -.021 & -.178 & .859 \\
\hline & Empathy & .185 & .238 & .120 & .777 & .440 \\
\hline & Tangible & -.068 & .327 & -.022 & -.209 & .835 \\
\hline
\end{tabular}

The above model summary indicates that there remains a correlation between independent variables (Reliability, Responsiveness, Assurance, Empathy and Tangible) and dependent variable (overall satisfaction from room service). At $5 \%$ significant level the correlation is $54.1 \%$. The value of adjusted $\mathrm{R}$ Square is .242.From ANOVA

test, it can be remarked that there is a statistically significant effect of Responsiveness on overall satisfaction level from room service but there is no statistical significant effect of others variables.

So, Overall Satisfaction $=.208+(.035)$ Reliability $+(1.003)$ Responsiveness + (-.034) Assurance+ (.185) Empathy + (-.068) Tangible.

6.2.5 Regression between overall satisfaction from room service and development of hospitality and tourism industry in Bangladesh:

Model Summary

\begin{tabular}{|l|l|l|l|l|}
\hline Model & R & R Square & Adjusted R Square & Std. Error of the Estimate \\
\hline 1 & $.407^{\mathrm{a}}$ & .166 & .154 & 1.331 \\
\hline
\end{tabular}

a. Predictors: (Constant), Overall satisfaction from room service.

ANOVA $^{b}$

\begin{tabular}{|c|c|c|c|c|c|c|}
\hline \multicolumn{2}{|c|}{ Model } & Sum of Squares & df & Mean Square & $F$ & Sig. \\
\hline \multirow[t]{3}{*}{1} & Regression & 25.369 & 1 & 25.369 & 14.326 & $.000^{\mathrm{a}}$ \\
\hline & Residual & 127.496 & 72 & 1.771 & & \\
\hline & Total & 152.865 & 73 & & & \\
\hline
\end{tabular}

a. Predictors: (Constant), Overall satisfaction from room service.

b. Dependent Variable: Development of hospitality and tourism industry in Bangladesh.

Coefficients $^{\mathrm{a}}$

\begin{tabular}{|c|c|c|c|c|c|c|}
\hline \multirow{2}{*}{\multicolumn{2}{|c|}{ Model }} & \multicolumn{2}{|c|}{ Unstandardized Coefficients } & \multirow{2}{*}{\begin{tabular}{|l}
$\begin{array}{l}\text { Standardized } \\
\text { Coefficients }\end{array}$ \\
Beta
\end{tabular}} & \multirow[b]{2}{*}{$\mathrm{t}$} & \multirow[b]{2}{*}{ Sig. } \\
\hline & & B & Std. Error & & & \\
\hline \multirow[t]{2}{*}{1} & (Constant) & 1.920 & .482 & & 3.984 & .000 \\
\hline & $\begin{array}{l}\text { Overall satisfaction from room } \\
\text { service. }\end{array}$ & 477 & .126 & .407 & 3.785 & .000 \\
\hline
\end{tabular}

a. Dependent Variable: Development of hospitality and tourism industry in Bangladesh.

The above model summary indicates that there remains a correlation between independent variable (Overall satisfaction from room service) and dependent variable (Development of hospitality and tourism industry in Bangladesh). At 5\% significance level the correlation is $40.7 \%$. The value of adjusted R Square is 
0.154 that means $15.4 \%$ of dependent variable can be explained by the independent variable. From ANOVA test, it can be remarked that there is a statistically significant effect of overall satisfaction from room service on development of hospitality and tourism industry in Bangladesh because significance level of the variable .000 which is less than $5 \%$. Hence $\mathrm{H6}_{0}$ is rejected and $\mathrm{H6}_{\mathrm{a}}$ is accepted and the regression equation will be:

Development of hospitality and tourism industry in Bangladesh $=1.920+(.477)$ Overall satisfaction from room service.

\section{Conclusion And Recommendations}

7.1. Conclusion: During the last five years (2006-2010) Bangladesh received a total number of $15,29,000$ visitors and earned US\$ 413.00 million. The World Travel and Tourism Council (WTTC) and UNWTO reports say that the pace of growth in the developing countries, including Bangladesh, is faster than in developed nations. (archive.thedailystar.net). This earning can be increased if the satisfaction level of customers can be increased. Hotel City Inn Limited, Khulna is playing a significant role in attracting and retaining the customers by satisfying them. This study revealed that marital status, responsiveness, assurance and tangible have statistically significant effect on overall satisfaction level from restaurant services whereas for room service marital status, income, room booking system and responsiveness have statistically significant effect on the overall satisfaction. This research has also found that there is statistically significant effect of overall customer' satisfaction from room service on the development of hospitality and tourism industry in Bangladesh.

7.2. Recommendations: Suggestions and recommendations have been developed on the basis of findings. To satisfy the customers Hotel City Inn Limited can adopt the following suggestions:

- The hotel should redesign their pricing strategy in a more competitive way to satisfy the customers.

- Hotel City Inn Limited should try to perform the service according to its promise.

- It should give more importance on time management.

- City Inn Limited should arrange training program to train the food server so that they provide the service in an excellent way.

- It should give more importance on food quality.

- It should take necessary steps to provide the service quickly

- The hotel should be more careful to listen and solve customer problem.

- The hotel should redesign the baggage counter, lobby and breakfast quality to attract and retain customers.

- Development of tourism industry depends on overall satisfaction of customers. So City Inn Limited should give the most priority to satisfy the customers.

\section{References}

[1]. Akbaba, A. (2006). Measuring service quality in the hotel industry: A study in a business hotel in Turkey. International Journal of Hospitality Management, 25(2), 170-192.

[2]. Andale, S. S., \& Conway, C. (2006). Customer satisfaction in the restaurant industry: an examination of the transaction-specific model. Journal of Services Marketing, 20(1), 3-11

[3]. Buhalis, D., \& Law, R. (2008). Progress in information technology and tourism management: 20 years on and 10 years after the Internet-The state of eTourism research. Tourism management, 29(4), 609-623.

[4]. Camisón, C. (1996). Total quality management in hospitality: an application of the EFQM model. Tourism management, 17(3), 191-201.

[5]. Chi, C. G. Q., \& Qu, H. (2008). Examining the structural relationships of destination image, tourist satisfaction and destination loyalty: An integrated approach. Tourism management, 29(4), 624-636.

[6]. Chi, C. G., \& Gursoy, D. (2009). Employee satisfaction, customer satisfaction, and financial performance: An empirical examination. International Journal of Hospitality Management, 28(2), 245-253.

[7]. Chu, R. K., \& Choi, T. (2000). An importance-performance analysis of hotel selection factors in the Hong Kong hotel industry: a comparison of business and leisure travelers. Tourism management, 21(4), 363-377.

[8]. Dominici, G., \& Guzzo, R. (2010). Customer satisfaction in the hotel industry: A case study from Sicily. International Journal of Marketing Studies, 2(2), 3.

[9]. Eraqi, M. I. (2006). Tourism services quality (Tour ServQual) in Egypt: the viewpoints of external and internal customers. Benchmarking: An International Journal, 13(4), 469-492

[10]. Gruen T. W., Summers J. O., \& Acito, F. (2000). Relationship marketing activities, commitment, and membership behaviors in professional associations. Journal of Marketing, 64 (3), 34-49.

[11]. Heung, V. C. (2000). Satisfaction levels of mainland Chinese travelers with Hong Kong hotel services. International Journal of Contemporary Hospitality Management, 12(5), 308-315.

[12]. Kandampully, J. (2000). The impact of demand fluctuation on the quality of service: a tourism industry example, Managing Service Quality, 1(10), 10-18.

[13]. Kandampully, J., \& Suhartanto, D. (2000). Customer loyalty in the hotel industry: the role of customer satisfaction and image. International journal of contemporary hospitality management, 12(6), 346-351.

[14]. Kozak, M., \& Rimmington, M. (1998). Benchmarking: destination attractiveness and small hospitality business performance. International Journal of Contemporary Hospitality Management, 10(5), 184-188.

[15]. Lam T., \& Zhang H. (1999). Service quality of travel agents: the case of travel agents in Hong Kong. Tourism Management, 20, 341-349. 
[16]. LeBlanc, G., \& Nguyen, N. (1996). An examination of the factors that signal hotel image to travellers. Journal of vacation Marketing, 3(1), 32-42.

[17]. Min, H., Min, H., \& Emam, A. (2002). A data mining approach to developing the profiles of hotel customers. International Journal of Contemporary Hospitality Management, 14(6), 274-285.

[18]. Namkung, Y., \& Jang, S. S. (2008). Are highly satisfied restaurant customers really different? A quality perception perspective. International Journal of Contemporary Hospitality Management, 20(2), 142-155.

[19]. Nash, R., Thyne, M., \& Davies, S. (2006). An investigation into customer satisfaction levels in the budget accommodation sect or in Scotland: a case study of backpacker tourists and the Scottish Youth Hostels Association. Tourism Management, $27(3), 525-532$.

[20]. Pizam, A., \& Ellis, T. (1999). Customer satisfaction and its measurement in hospitality enterprises. International Journal of Contemporary Hospitality Management, 11(7), 326-339.

[21]. Poon, W. C., \& Low, K. L. T. (2005). Are travellers satisfied with Malaysian hotels?. International Journal of Contemporary Hospitality Management, 17(3), 217-227.

[22]. Ryu, K., Han, H., \& Kim, T. H. (2008). The relationships among overall quick-casual restaurant image, perceived value, customer satisfaction, and behavioral intentions. International Journal of Hospitality Management, 27(3), 459-469

[23]. Sin, L. Y., Tse, A. C., Heung, V., \& Yim, F. H. (2005). An analysis of the relationship between market orientation and business performance in the hotel industry. International Journal of Hospitality Management, 24(4), 555-577.

[24]. Su, A. Y. L. (2004). Customer satisfaction measurement practice in Taiwan hotels. International Journal of Hospitality Management, 23(4), 397-408.

[25]. Tsang, N., \& Qu, H. (2000). Service quality in China's hotel industry: a perspective from tourists and hotel managers. International Journal of Contemporary Hospitality Management, 12(5), 316-326.

[26]. Yen A., \& Su L. (2004). Customer satisfaction measurement practice in Taiwan hotels. Hospitality Management, 23,397-408.

\section{Websites}

[1]. http://archive.thedailystar.net/beta2/news/tourism-industry-in-bangladesh/ accessed on 12/9/2014

[2]. http://www.cityinnltd.com/ accessed on 13/09/2014 